\title{
Adulteration of butterfat: validity of Reichert-Meissl, Polenske and iodine values
}

\author{
By N. A. Youness \\ Animal Production Research Institute - Dairy Technology \\ Department, Dokki, Cairo, Egypt.
}

\section{RESUMEN}

Adulteración de grasa de manteca: validez de los indices de Reichert-Meissl, Polenske e iodo.

Durante las estaciones de invierno y verano se obtuvo grasa de leche de búfalo. Sebo de vaca (grasa del corazón) se adquirió del mercado local. El sebo de vaca se añadió a la grasa de leche de verano en las relaciones $5 \%, 10 \%, 15 \%$ y $50 \% \mathrm{w} / \mathrm{w}$. Se aplicó la cromatografía en capa fina para obtener la fracción de triglicéridos de cada muestra obtenida. La cromatografía gaseosa se usó para identificar el contenido en ácidos grasos de la grasa de leche de invierno, verano y las mezclas. También se determinaron para cada muestra los índices de ReichertMeissl (RM), Polenske (P) e lodo. Se concluyó que los (RM) de la grasa de leche de invierno y de verano fueron $25.52 \pm 0.511$ y $28.74 \pm 0.568$ respectivamente. Los índices $(P)$ y de iodo fueron $1.94 \pm 0.162,2.53 \pm 0.146$ y $42.1 \pm 0.85,30.33 \pm 0.839$ en los mismos aspectos. La adición de sebo de vaca a la grasa de leche en las relaciones $5 \%$ y $10 \%$ no afectó los indices (RM) y (P) de las mezclas resultantes. La presencia del 15\% de sebo de vaca en la grasa de leche afectó ligeramente los índices (RM), (P) e iodo. La adición del $50 \%$ de sebo de vaca a la grasa de leche sacó los valores de $(R M)$ y $(P)$ del rango normal, permaneciendo dentro del mismo el índice de iodo. Se observó también que la adición de sebo de vaca en las relaciones $5 \%, 10 \%$ y $15 \%$ a la grasa de leche de verano, mejoró el comportamiento de los ácidos grasos de la grasa de leche, mientras que el $50 \%$ de sebo de vaca en la grasa de leche, disminuyó todos los ácidos grasos de cadena corta. La determinación de los indices (RM), (P) e iodo para detectar sebo de vaca como adulterante en grasa de leche pura no es suficiente al $5 \%$ y $10 \%$ de sebo de vaca en la grasa de leche.

PALABRAS-CLAVE: Adulteración (detección) - Grasa de leche - Sebo de vaca.

\section{SUMMARY}

Adulteration of butterfat: validity of Reichert-Meissl, Polenske and iodine values.

Buffaloe's milkfat was obtained during the winter and the summer seasons. The beef tallow (Heart fat) was purchased from the local market. Beef tallow was added to the summer milkfat in the ratios $5 \%, 10 \%, 15 \%$ and $50 \% \mathrm{w} / \mathrm{w}$. Thin layer chromatography was applied to obtain the triglycerides fraction of each sample obtained. Gas chromatography was used to identify the fatty acid content of the winter, summer and the admixtures. Reichert-Meissl (RM), Polenske $\left(P_{)}\right)$and lodine values were also determined for each sample. It was concluded that the (RM) of the winter and the summer milkfat were $25.52 \pm 0.511$ and $28.74 \pm 0.568$, respectively. The $(P)$ and iodine values were
$1.94 \pm 0.162,2.53 \pm 0.146$ and $42.1 \pm 0.85,30.33 \pm 0.839$ in the same respect. The addition of beef tallow to the milkfat in the ratios $5 \%$ and $10 \%$ did not affect the (RM) and (P) values of the resultant admixtures. The presence of $15 \%$ beef tallow in milkfat slightly affected the (RM), (P) and iodine values. The addition of $50 \%$ beef tallow to the milkfat got the values of (RM) and (P) out of the normal range. The iodine values was still within the norma range of milkfat. It was also observed that the addition of bee tallow in the ratios $5 \%, 10 \%$ and $15 \%$ to summer milkfat, improved the fatty acid pattern of the milk fat, while the $50 \%$ beef tallow in milkfat, decreased all the short chain fatty acids. The determination of the (RM), (P) and iodine values to detect the beef tallow as an adulterant in pure milkfat is not sufficient at $5 \%$ and $10 \%$ beef tallow in milkfat.

KEY-WORDS: Adulteration (detection) - Beef tallow - Milkfat.

\section{INTRODUCTION}

Adulteration of butterfat with competitive fats had been studied by many investigators. The common methods of detecting such adulteration has consisted in determining the fatty acid composition of the fat obtained from the suspected product (1) (2). However, the microscopic appearance and the melting point of a fat sterol acetate could greatly assist in detecting the vegetable fat in butter fat (3). Concerning the trans isomer content, the genuiness of a suspected sample could be proved by measuring the trans isomer content of such sample. The presence of the trans isomer in a milkfat sample is a sufficient evidence to the presence of hydrogenated oil (4). In other study to detect the adulteration in butterfat, it was found that the $B$ sitosterol is the predominant sterol of the cottonseed oil, while the cholesterol was the principal sterol of the beef tallow. The beef tallow could not be detected in butterfat up to $6 \%$ beef tallow in butterfat, while cottonseed oil was easly detected even at $2 \%$ cottonseed oil in butterfat (5). Fatty acid percentage esterfied in the 2-position of the triglycerids of milkfat and beef tallow was calculated, using gas chromatography. The presence of $2 \%, 4 \%$ and $6 \%$ beef tallow in the milkfat was detected (6). However, many investigators determined certain fat constant values to detect the adulteration in a suspected fat, which were, the butyric 
acid content (7). Reichart-MeissI and Polenske values (8), gas chromatographic analysis of two fractions obtained by fractional crystalization ( 9 ) and fatty acids ratio of authentic and adulterated milkfat (10).

The author attempts in this work, to evaluate the validity of some common determinations to detect the adulteration of butterfat with other animal fat.

\section{MATERIALS AND METHODS}

\section{- Source of samples and sampling}

Buffaloe's milk samples were collected during the winter as well as the summer seasons, from the herd of Sakha Experimental Station, Animal Production Research Institute. The animal were mainly fed Egyptian clover and concentrate mixture during the winter season, while it fed rice hay and concentrate mixture during the summer season. The sampling was repeated 5 times in both seasons. Milk fat was extracted from each sample after centrifuging, by melting and the fat was filtered. Beef tallow (Heart fat) was purchased from the local (slaughter house). The (chloroform methanol 2-1 v/v) system was applied to extract the fat from tissue. Solvents were evaporated using a rotary evaporator.

The milkfat of winter season was taken as a control due to the balanced plan of nutrition during the winter season. The milkfat of the summer season was mixed with the beef tallow in the ratios $5 \%, 10 \%, 15 \%$ and $50 \% \mathrm{w} / \mathrm{w}$ beef tallow in milkfat. The obtained admixtures were melted separately to obtain good homogenity, and then, a proper amount was taken from each sample for analysis.

\section{- Separation of the samples triglycerides}

A preparative thin layer chromatography (TLC) was applied to separate the triglyceride fraction of each sample (11).

\section{- Methylation}

Triglyceride fatty acids were converted to the corresponding methyl esters using methanol, zinc chloride and zinc dust as a catalyst (12).

\section{- Chromatographic analysis}

The determination of the resulted fatty acids methyl esters was carried out using a gas chromatograph, type Hewlett-Packard 5840A, with double flame ionization detector and with multilevel temperature programmer provided with a HP-5840A terminal. Column used was a 6 feet stainless steel packed with $10 \%$ UCW 928 on chromosorb W. AM, DMCS treated, 80100 mesh (Hewlett Packard). Carrier gas used was nitrogen. The conditions were as follows: length of column, 6 feed, with internal diameter $1 / 8$ inc. Programming temperature $140-300^{\circ} \mathrm{C}, 8^{\circ} \mathrm{C} / \mathrm{min}$. Detector temperature $300^{\circ} \mathrm{C}$, injection port temperature $230^{\circ} \mathrm{C}$. Carrier gas flow rate $\left(\mathrm{N}_{2}\right) 40 \mathrm{ml} / \mathrm{min}$. Hydrogen flow rate $40 \mathrm{ml} / \mathrm{min}$. Air flow rate $300 \mathrm{ml} / \mathrm{min}$.

\section{- Reichert, Polenske and lodine determinations}

The Riechert, Polenske and lodine values were determined for each sample as described by Bolton and Rvis (13).

\section{RESULTS AND DISCUSSION}

Present data shows the fatty acid composition as well as some constants of winter and summer buffaloe's milkfat. It obvious that both of fats had the same fatty acid pattern. On one hand, the winter milkfat characterized with a high percentage of $\mathrm{C}_{18}$ unsaturated and low levels of short chain fatty acids. On the other hand, the summer milkfat had higher levels of saturated fatty acids, and short chain fatty acids, than the one found in the pattern of winter milkfat. However, this discrepancy between both fats in their fatty acid levels was due to the effect of the season of the year and consequently the plan of nutrition (14) (15) (16). From the same table, the iodine value was found to be higher in winter milkfat than that found in the summer milkfat. The iodine value ranged from $30.33 \pm 0.839$ in summer milkfat to $42.10 \pm 0.850$ in winter milkfat (17). The same data contained the RiechertMeissl (RM) and Polenske value (P). It is clear that the $(\mathrm{RM})$ ranged from $25.52 \pm 0.511$ in the winter to $28.74 \pm 0.568$ in the summer, while the $(P)$ ranged from $1.94 \pm 0.162$ to $2.53 \pm 0.146$, respectively. The previous findings were expected because the summer milkfat contained higher levels of $\mathrm{C}_{4}$ and $\mathrm{C}_{6}$ acids than the one found in winter milkfat (18) (19). The fatty acid pattern of beef tallow, also in the table, revealed high contents of $C_{18: 0}$ and $C_{18: 1}$ acids. However, these acids besides $C_{16}$ acid are found to be characteristic for the beef tallow. The iodine values was 54.55 .

The admixtures of $5 \%, 10 \%, 15 \%$ and $50 \%$ beef tallow in the summer butterfat are also reported in the Table. The fatty acid content of the admixtures revealed that the fatty acids $\mathrm{C}_{4}-\mathrm{C}_{14}$ were decreased as the added beef tallow increased. On the other hand, $\mathrm{C}_{18}$ acids were increased by the addition of beef tallow to the summer milkfat. These observations are due to the absence of the short chain fatty acids, and the higher content of the $C_{18}$ acids of the beef tallow (19). The effect of the addition of beef tallow to the milkfat on the iodine, (RM) and (P) values are shown in the table. Several investigators reported that the iodine, $(\mathrm{RM})$ and $(\mathrm{P})$ values ranged from 29.1-41.1, 24.2433.55 and 1.92-2.95, respectively (20) (21). From the previous results it can be concluded that the additon 
Table

Fatty acid composition of buffaloes' milkfat during winter and summer seasons, and of beef tallow and admixtures with beef tallow including the IV, RM and $P$ values.

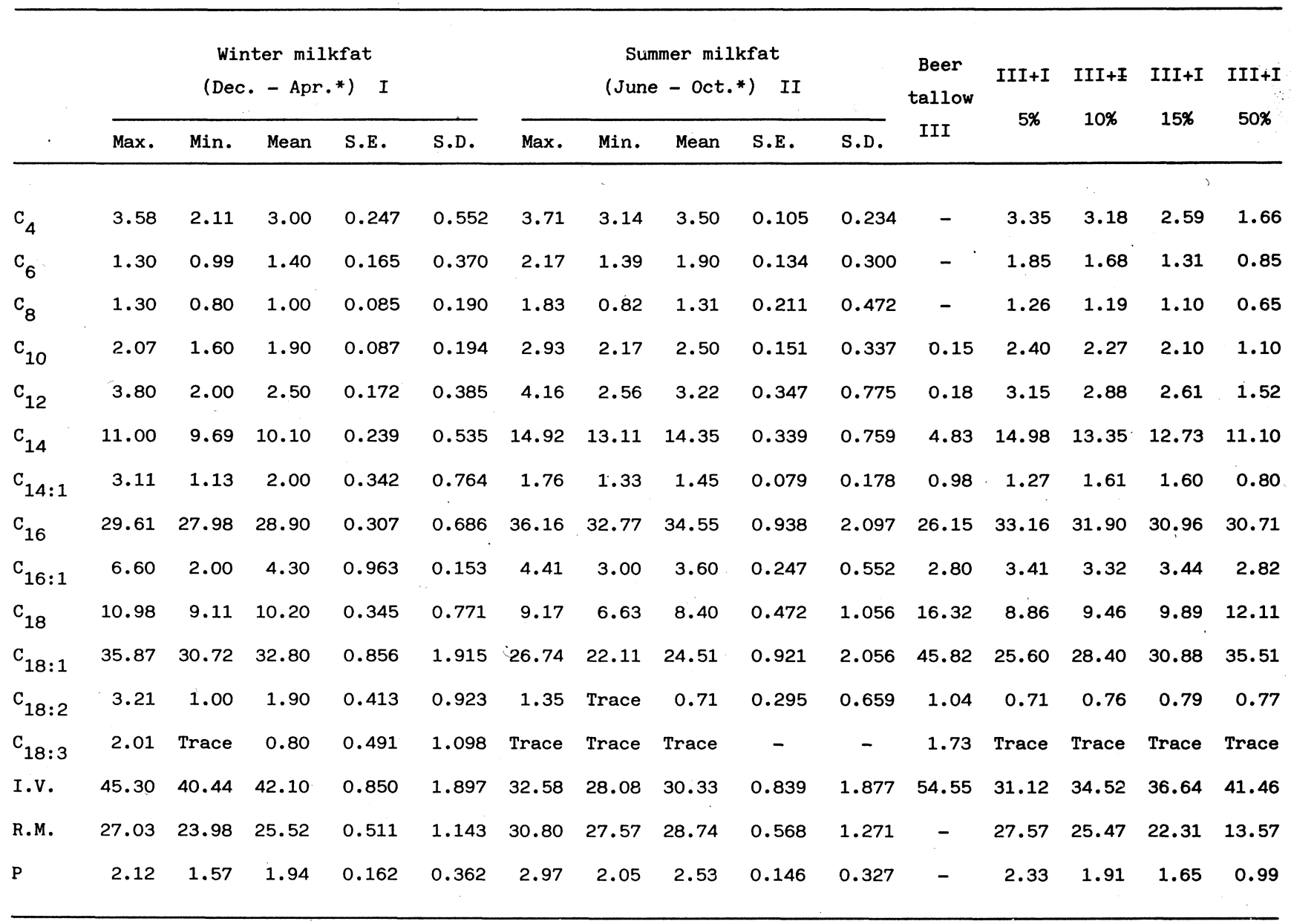

* Ration was alfalfa + concentrates

I.V. : Iodine value
** Ration was concentrates + rice hay

R.M. : Riechert-Meissl

P: Polenske value of beef tallow to the summer milkfat did not affect the iodine value even at $50 \%$ beef tallow in milkfat. The ratios $5 \%$ and $10 \%$ beef tallow in milkfat did not affect the (RM) and $(P)$ values being within the range of the pure milkfat, analysed or reported. The percent of $15 \%$ beef tallow in.milkfat slightly affected the iodine, (RM) and $(P)$ values. The addition of $50 \%$ beef tallow in milkfat got the values of $(R M)$ and $(P)$ out of normal range (1.57-2.12) of the winter milkfat. On the other hand, the addition of $5 \%, 10 \%, 15 \%$ beef tallow in milkfat improved the fatty acid pattern of the summer milkfat, while the $50 \%$ decreased all the short chain 
beef tallow as adulterant in pure milkfat is not sufficient at $5 \%$ and $10 \%$ beef tallow in milkfat.

\section{REFERENCES}

1. Mannaert, P.- "Study of butterfat in Belgium Region 1".Dairy Sci. Abst. 37 (1975) 8, 5118.

2. Youness, N.A. and Nasr, M.A.- "Fatty acid content of imported butter oiln"-- Grasas y Aceites 39 (1988) 242-244.

3. Official Methods of Analysis.- $9^{\text {th }}$ Ed.- Association of Official Agricultural Chemists, Method 26, 049, Washington, D.C., 1960.

4. Youness, N.A. and Soliman, Mervat, A.- "Adulteration of butterfat: trans-unsaturation content".- Grasas y Aceites 39 (1988) 69-71.

5. Youness, N.A. and Soliman, Mervat, A.- "Adulteration of Butterfat: Sterol composition".- Grasas y Aceites 38 (1987) 372-374.

6. Soliman, Mervat, A., and Youness, N.A.- "Adulteration of butterfat: Fatty acid composition of triglycerides and 2-monoglycerides".- J. Am. Oil Chemists' Soc. 63 (1986) 248250.

7. Mark Keeney.- "A survey of United States butterfat constants. II. Butyric acid".- Association Official Agric. Chemists 39 (1956) 212-225.

8. Valentino, F.P.; Boniforti, L.; Monicelli, R.- "Reichert-Meiss and Polenske values: Composition and gas chromatographic determination of soluble and insoluble acids in butter".-Dairy Sci. Abstr. 28 (1965) 3, 1008.

9. Farag, R.S.; Hewedi, M.M.; Abou-Raya, S.H. and Khalifa, H.H.- "Detection of cow milk admixture to buffalo milk". J. Am. Oil Chemists' Soc. 61 (1984) 5.

10. Youness, N.A. and Soliman, Mervat A.- "Adulteration of butterfat with other sources of fat".- Grasas y Aceites 37 (1986) 200-203.

11. Stahl, E.- In "Thin layer chromatography".- p. 149.- Academic Press, New York and London, 1965.

12. Shahin, Y.- "Contents of row milk free fatty acids in respect of production factories".- Thesis, Justus Liebig, Univ. Giessen, W. Germany, 1977.

13. Williams, K.A.- In "Oils, fats and fatty foods. Their practical examination".- $3^{\text {rd }}$ Ed.- J \& A Churchill Ltd. London, 1950 , p. 109.

14. McDowall, F.H. and McGillivary, W.A.- "Studies on the properties of New Zealand butterfat, VI. Comparison of the properties and vitamin $A$ potencies of butterfats produced by clover-fed and ryegrass-fed dairy cows.- $J$. Dairy Res. 30 (1963) 47.

15. Hall, A.J.- "Seasonal and regional variations in the fatty acid composition of milkfat".- Dairy Industries 35 (1) (1970) 20-24.

16. Gray, I.K.- "Seasonal variations in the composition and thermal properties of New Zealand milk fat, I. Fatty acid compositionn.- J. Dairy Res. 40 (1973) 207-214.

17. Svensen, A. and Ystgaard, O.M.- "Fatty acid composition of Norwegian butterfat". - Dairy Sci. Abstr. 28 (1966) 11 , 3699.

18. Laurelle, L., Dijck, M. Van, Daenens, P.- "Fatty acid composition of Reichert-Meissl and Polenske fractions in butterfat" - J. Dairy Res. 43 (1976) 1, 137-140.

19. Hatipoglu, M.- "Chemical investigations on butters collected from different region of Turkey".- Dairy Sci. Abst. 35 (1972) 11, 4817.

20. Steen, K. and Andersen, J.O.- "Seasonal variations in Danish butterfat composition".- Dairy Sci. Abst. 36 (1974) 9, 4197.

21. Zehren, V.L. and Jackson, H.C.- "A survey of United States butterfat constants, I. Reichert-Meissl, Polenske and Refractive Index Values". - Association Official Agric. Chemists 39 (1956) 194-212.

22. Parry, R.M., Sampugna, JR. J. and Jensen, R. G.- "Effect of feeding sufflower oil on the fatty acid composition of milkn.- J. Dairy Sci. 47 (1964) 37-40.

23. Saitc, T. Onuma, T., Nakunishi, T.- "Effect of grass and legumes fed on fatty acid composition of lipids in cows, milk, IX. Effects of dietary linseed oil".- Dairy Sci. Abstr. 33 (1971) 5, 2609.

(Recibido: Septiembre 1990) 